\title{
Optimal Environmental Conditions for Yam Storage in South East (Tropical) Zone of Nigeria
}

\author{
E.A. Udom ${ }^{1}$, S.I. Oluka², P.C. Eze ${ }^{3}$ \\ ${ }^{1}$ Abak Irrigation Project, Cross River Basin Development Authority, Calabar, Nigeria. \\ ${ }^{2,3}$ Department of Agricultural \& Bioresource Engineering, Enugu State University of Science \& Technology Enugu, Nigeria.
}

\begin{abstract}
Yam storage methods in Nigeria were studied, evaluated and compared. Among the storage methods studied, evaluated and compared include designed barn, traditional barn, house and pit storages. The parameters taken to assess their performance were tuber weight loss, rotting, sprouting and pest infestation after fourteen (14) weeks of storage. Designed barn storage methods with weight loss of $29.6996 \mathrm{~kg}$ was compared to other storage methods with weight loss value of $58.199 \mathrm{~kg}$ (pit storage) $46.800 \mathrm{~kg}$ (house storage) and $47.8002 \mathrm{~kg}$ (traditional storage) from the big tuber sizes $(1.5-1.8 \mathrm{~kg})$. From the small tuber size $(0.7-0.9 \mathrm{~kg})$, the weight loss recorded from each storage methods included, designed barn 24.2004kg; pit storage44.8994kg; house storage $43.4994 \mathrm{~kg}$ and traditional barn $46.6004 \mathrm{~kg}$. Rotting was recorded nil from designed barn for both big tubers and small tubers and 10 tubers each were recorded from pit house and traditional barn for big tubers, pit storage recorded 20 tubers and others recorded nil for small tubers. Records on sprouting indicated the following numbers of tubers from each storage methods. From the big tubers set, designed barn had 20 tubers sprouting within 14 weeks duration but pit had 30 tubers while house storage had 20 tubers and traditional barn 30 tubers sprouted. From small sized tubers, records on sprouting indicated the following, designed barn nil, pit storage 80 tubers, house storage 40 tubers and traditional 60 tubers. Data collected from each storage facility were statistically analyzed and compared using Completely Randomized Design (CRD), ANOVA, standard deviation and LSD). Designed storage structure is recommended for use by yam farmers to alleviate their losses after harvest and to help farmers prolong the life span of their produce for future use as food, planting materials, industrial use and commercial uses.
\end{abstract}

Keywords—Barn, weight loss, rotting, sprouting, storage, yam.

\section{INTRODUCTION}

Yam is an important staple food crop in tropical Africa, the Pacific and the Caribbean (Adesuji, 1982).In Nigeria the most widely available or most prevalent species are the white yam (Dioscorearotundata) and the yellow yam (Dioscoreacayenensis). But the most common species worldwide is the water yam (Dioscoreaalata).Most Nigerians consider yam as the best of all staple foods. It is noteworthy to mention that yam is not only the most preferred staple food in the country on the basis of taste and texture, it is also the most widely acceptable food served at important occasions (Terry et al., 1983). Yam tuber is prepared for consumption in a variety of ways. These include boiling, pounding, frying and baking. The prepared yam is normally consumed with soup, meat, stew, fish or green vegetables (Mabel, 1999). Yam plays an important role in social and religious festivals. In fact in the yam growing area, yam is a vital integral part of the cultural heritage for many people (Coursey, 1975). In Nigeria, the yam festival marks the earliest date on which new yam may be harvested or eaten. It ensures that the crop is ushered in formally and that its consumption does not occur until the community gives thanks to God and celebrates the event. Yam is normally cultivated as an annual crop, and is required in good condition for germination and propagation, as well as in good texturally sound state throughout the year for good food preparation. Conservative estimate indicate that about $15 \%$ of yam produced do not reach the market mainly because of post-harvest losses which occurs as a variety of pest, rotting, respiration, sprouting and dehydration (Courtney, 1983, Booth, 1974). These occur due to lack of appropriate storage facilities. There is the need for consideration of suitable design and development of an environment - friendly storage structure for yams. Though scientific storage such as refrigeration (Booth, 1974), curing (Gonzalez and Collazo de River, 1972), chemical treatment (Passam et al., 1976), high temperature treatment (Martin, 1955) and irradiation (Rivera et al., 1974) have been recommended, but none of these measures have been widely adopted due to their complex nature of the technology to the farmers who are currently using traditional methods (Wilson, 1980).To prevent losses, simple and economic yam storage structures are required. 
There is also the need for consideration of a suitable design and development of environment - friendly storage structure for yams. It is hereby considered that the need for an appropriate and economic yam storage structure had to start with a proper understanding of the available traditional storage facilities in Nigeria with a view to examining their structural and environmental limitations, as well as seek for appropriate improvement. This is the thrust of this study on yam storage methods.

\section{MATERIALS AND METHODS}

\section{EQUIPMENTS.}

Materials and equipment used include Bamboo wood, nails, rope, oil palm leaves (raffia), tape, hammer, weighing balance (with an accuracy of $\pm 0.05 \mathrm{~kg}$ ), thermometer (with an accuracy of $\pm 0.01^{\circ} \mathrm{C}$ ) and hacksaw. The relative humidity was observed and recorded from CRBDA meteorological station. Also, the air velocity of the environment was observed and recorded from the Nigerian Meteorological Agency, Uyo, Akwa Ibom State.

\section{LOCATION.}

This research study is located at Abak Irrigation Project of the Cross River Basin Development Authority, Calabar, which lies within latitude $4^{\circ} 58^{\prime \prime}$ and longitude $7^{\circ} 48^{\prime \prime}$ with an elevation of $30 \mathrm{~m}$ above sea level.

\section{EXPERIMENTAL PROCEDURE}

Four yam storage facilities were used namely; New Designed/Udom yam storage, Traditional storage, Traditional yam barn, House storage and Pit storage yam barn. The four storage facilities were stored with equal weight of yam tubers $(360 \mathrm{~kg})$ comprising of two hundred (200) small yam tubers $(0.70 \mathrm{~kg}$ in size) and big size yam tubers of $1.50 \mathrm{~kg}$, numbering one hundred (100) tubers. Both small size and big size yam tubers $(0.7 \mathrm{~kg}$ and $1.5 \mathrm{~kg})$ weighing $180 \mathrm{~kg}$ (one hundred and eighty) respectively and numbering two hundred (200) and one hundred (100) tubers were stored per facility and observed through fourteen weeks based on weight loss, rotting, sprouting and pest infestation. The experimental design was completely randomized with four (4) replications. Data collected from each storage facility were statistically analyzed and compared by using ANOVA standard deviation and least significant difference method (LSD).

\section{THE DESIGNED YAM BARN}

The Designed yam storage facility structure was constructed having a floor space size of 450 by $300 \mathrm{~cm}^{2}\left(135,000 \mathrm{~cm}^{2}\right)$. It has a height of $300 \mathrm{~cm}$ from the ground level with bamboo frame work and bamboo bedding material plastered together by nails and ropes to make it more rigid. A shade is provided at the top of the structure by the use of palm tree leaves leaving adequate space for ventilation (see fig. 1). The yam tubers are arranged in line leaving some space beside each line of tubers for proper air circulation within the structure (see fig. 2). The palm leaves which dried up after some time are replaced by fresh one to ensure adequate protection from sun rays and effective cooling of the storage environment (Courtney, 1967). The effectiveness of this structure is dependent on natural air circulation within the structure, the cooling and provision of shade to the structure to regulate the storage temperature, regulation of relative humidity through natural ventilation of the structure and in addition to the arrangement of the tubers in the structure (see fig. 3). Daily records of temperature of the facility were obtained for fourteen weeks. Weight of tubers were observed and recorded within the fourteen weeks duration. Other records obtained include relative humidity and wind velocity. The general sanitation of the surrounding were regularly maintained to avoid insect attack and disease.

\section{DEAD LOAD FACTOR}

A row of $(0.9 \times 20) \mathrm{kg}$ tubers of yam

$=18 \mathrm{~kg}$ (small tubers of $0.9 \mathrm{~kg})$

Or $(1.8 \times 10) \mathrm{kg}$ $=18 \mathrm{~kg}$ (big tubers of $1.8 \mathrm{~kg})$

Area of designed yam barn $(450 \times 300) \mathrm{cm}^{2}$ $=135,000 \mathrm{~cm}^{2}$

Total weight of yam in $\mathrm{kg}$ in the designed yam barn $=360 \mathrm{~kg}$

\section{TRADITIONAL YAM BARN}

Traditional barn are shed with woven sticks walls and thatched roof (tuber and root crops manual, 1982). They may be in form where tubers are tied on vertical stakes in shaded or un-shaded area (fig 3). Yam tubers of both small and big size of 0.7 and 1.5 totaling 300 tubers (200 tubers of small size of $0.7 \mathrm{~kg}$ and 100 tubers of big size of $1.5 \mathrm{~kg}$ weighing $180 \mathrm{~kg}$ per set were used in this research work. Records on weight loss, temperature, relative humidity, wind velocity, sprouting and rotting were observed under fourteen (14) weeks.

\section{HOUSE STORAGE}

House floor of space of 450 x $300 \mathrm{~cm}\left(135,000 \mathrm{~cm}^{2}\right)$ was used to store three hundred (300) yam of both small and big size of 0.7 and $1.5 \mathrm{~kg}$ and records on weight loss, temperature, relative humidity, wind velocity, sprouting and rotting kept for fourteen (14) weeks of storage. 


\section{PIT STORAGE}

Pit measuring $450 \times 300 \mathrm{~cm}\left(135,000 \mathrm{~cm}^{2}\right)$ to accommodate three hundred (300) yam tubers which comprised of small size $0.7 \mathrm{~kg}$ and $1.8 \mathrm{~kg}$ big sized are store to evaluate weight loss, sprouting and rotting for fourteen (14) weeks duration observed.

\section{WEIGHT LOSS}

\section{RESULTS AND DISCUSSION}

In the four storage structures namely Designed Barn, Pit Storage, House Storage and Traditional Storage, a set of big tubers of yam numbering 100 (hundred) and weighing $180 \mathrm{~kg}$ was stored in each of the storage structures for 14 (fourteen) weeks. The big tubers weight stored in the Designed Storage structure recorded a decrease from 180kg to $150.3004 \mathrm{~kg}$ indicated weight loss of $29.6996 \mathrm{~kg}$, while Pit Storage recorded a decrease from $180 \mathrm{~kg}$ to $121.8006 \mathrm{~kg}$, indicating a loss of weight of $58.1994 \mathrm{~kg}$. House Storage showed a loss of $46.8006 \mathrm{~kg}$, while Traditional Barn Storage recorded $47.8002 \mathrm{~kg}$ loss of weight out of $180 \mathrm{~kg}$ (Table 1 ).

Table.1:Big sized (1.5-1.8kg) yam tuber storage weight loss in $\mathrm{kg}$, percentage loss and average temperature in ${ }^{\circ} \mathrm{C}$ under different storage methods after 14 weeks.

\begin{tabular}{|l|c|c|c|l|l|}
\hline Storage Structure & $\begin{array}{l}\text { Original tuber } \\
\text { weight }(\mathbf{k g})\end{array}$ & $\begin{array}{l}\text { Weight after } \\
\mathbf{1 4} \text { weeks }(\mathbf{k g})\end{array}$ & $\begin{array}{l}\text { Weight loss in kg } \\
\text { after 14 weeks }\end{array}$ & $\begin{array}{l}\text { Percentage loss } \\
(\boldsymbol{\%})\end{array}$ & $\begin{array}{l}\text { Average } \\
\text { Temperature } \\
\left({ }^{\mathbf{}} \mathbf{C}\right)\end{array}$ \\
\hline Designed Barn & 180 & 150.3004 & 29.6996 & 16.4998 & 27.84 \\
\hline Pit Storage Barn & 180 & 121.8006 & 58.1994 & 32.333 & 29.16 \\
\hline House Storage & 180 & 133.1994 & 46.8006 & 26.0003 & 28.92 \\
\hline Traditional Barn & 180 & 1.32 .1998 & 47.8002 & 26.5557 & 29.72 \\
\hline
\end{tabular}

From the above records, decrease in weight of big tubers from the four structures were evaluated both in kilogram and percentage (table 1). The records indicated that the Designed Storage structure had the least weight loss of $29.6996 \mathrm{~kg}$, in the big tubers set, followed by House Storage which indicated 46.8006kg. The Traditional Barn Storage showed a loss of $47.8002 \mathrm{~kg}$ and the highest loss in weight was from the Pit Storage which was $58.1994 \mathrm{~kg}$.Evaluation in percentage indicated the following percentage in respect of each structure, Designed Structure had $16.4998 \%$, while Pit Storage had $32.333 \%$, House Storage had $26.0003 \%$ and
Traditional Barn Storage indicated a percentage loss of $26.5557 \%$. From the above records on the four storage structures on big tubers, Designed Storage facility showed the highest efficient storage performance on storing yam tubers which reduced post harvest loss to $16.4998 \%$. This also proves what other researchers work had proven like Booth (1974) and Coursey (1983). Also, the temperature of each storage facility were recorded as for each storage facility. From the data above, the Designed Barn produced the lowest temperature of $27.84^{\circ} \mathrm{C}$. This also contributed to its efficiency in storing the yam tubers.

Table.2: Small Sized (0.7-0.9kg) Yam tuber storage weight loss in kg, percentage loss and average temperature under different storage methods for 14 weeks.

\begin{tabular}{|l|c|c|l|l|c|}
\hline Storage Structure & $\begin{array}{l}\text { Original } \\
\text { tuber weight } \\
(\mathbf{k g})\end{array}$ & $\begin{array}{l}\text { Weight after } \\
\mathbf{1 4} \text { weeks } \mathbf{( k g )}\end{array}$ & $\begin{array}{l}\text { Weight loss in } \\
\text { kg after 14 } \\
\text { weeks }\end{array}$ & $\begin{array}{l}\text { Percentage } \\
\text { loss } \\
(\mathbf{\%})\end{array}$ & $\begin{array}{l}\text { Average Temperature } \\
\text { in }{ }^{\mathbf{}} \mathbf{C}\end{array}$ \\
\hline Designed Barn & 180 & 155.7996 & 24.2004 & 13.4447 & 27.84 \\
\hline Pit Storage Barn & 180 & 135.8006 & 44.8994 & 24.9441 & 29.16 \\
\hline House Storage & 180 & 136.5006 & 43.4994 & 24.1663 & 28.92 \\
\hline Traditional Barn & 180 & 133.1998 & 46.6004 & 25.8891 & 29.72 \\
\hline
\end{tabular}

Small tubers of yams numbering 200 tubers and weighing $180 \mathrm{~kg}$ (one hundred and eighty kilogram) in four sets were stored in the four storing structures (table 2). After fourteen (14) weeks, their respective decrease in weight in kilogram and percentage were recorded (table 2). Designed Barn Storage structure showed a decrease in weight of
$24.2004 \mathrm{~kg}$, which represent $13.4447 \%$ of weight loss (table 2), Pit Storage recorded $44.8994 \mathrm{~kg}$, that is $24.9441 \%$, while House Storage had a fall in weight of $43.4994 \mathrm{~kg}$, which accounted for $24.1663 \%$ and Traditional Storage had a weight decrease of $46.6004 \mathrm{~kg}$, which is $25.8891 \%$ (table 2). From the records on the table 2, the Designed Barn has 
performed outstandingly different by reducing the loss by 24.2004 which is $13.444 \%$ as compared to other storing structures. Also from the big tubers, the Designed Storage structure had significant different values of weight in $\mathrm{kg}$ of
29.6996 which is $16.4998 \%$ thus proving its storage efficiency in line with other research proposed range for safe storing of yams (Booth, 1994;Noon, 1978; Passam et al., 1974).

Table.3: ANOVA for big sized storage weight loss under different storage for 14 weeks at p<0.05.

\begin{tabular}{|l|l|l|l|l|l|}
\hline Source of variation & DF & SS & MS & F.cal & F.tab5\% \\
\hline Among treatment & 3 & 23.521 & 7.840 & 50.731 & 0.000 \\
\hline Within treatment & 52 & 8.036 & 0.555 & & \\
\hline Total & 55 & 31.557 & & & \\
\hline
\end{tabular}

From the above table (table 3), it is indicated that at least one of the storing structures of the big sized yam tuber has a significant difference in weight loss.

Table.4: ANOVA for small sized yam storage weight loss under different storage methods for 14 weeks at $p<0.05$.

\begin{tabular}{|l|l|l|l|l|l|}
\hline Source of variation & DF & SS & MS & F.cal & F.tab5\% \\
\hline Among treatment & 3 & 29.846 & 9.949 & 75.752 & .000 \\
\hline Within treatment & 52 & 6.829 & 0.131 & & \\
\hline Total & 55 & 36.676 & & & \\
\hline
\end{tabular}

The table 4 of ANOVA for small sized yam tuber also indicates a difference in weight loss from the four storage structures.

Table.5: Weight loss of big sized yam tuber from different storage methods and their standard deviation.

\begin{tabular}{|l|c|c|c|c|}
\hline Storage method & No of weeks & Mean (unit) & Standard Deviation & Standard Error 0.0055 \\
\hline Designed Barn Storage & 14 & 2.1214 & .40984 & 0.10953 \\
\hline Pit Barn Storage & 14 & 4.1571 & .40328 & 0.10778 \\
\hline House Storage & 14 & 3.3429 & 35456 & 0.09476 \\
\hline Traditional Barn Storage & 14 & 3.4143 & .26270 & 0.07021 \\
\hline Total & 56 & 3.2589 & .81660 & 0.10912 \\
\hline
\end{tabular}

Table 5 indicates $2.1214 \mathrm{~kg}$ mean weight loss from the designed barn which is the least when compare to pit storage mean weight loss of 4.1571 . House storage mean weight loss of $3.3429 \mathrm{~kg}$ and mean weight loss of traditional storage of $3.4143 \mathrm{~kg}$ and is better to use the designed barn in storing yam tubers for future use.

Table.6: Mean weight loss of small seized yam tuber for different storage methods standard deviation, and standard error

\begin{tabular}{|l|c|c|c|c|}
\hline Storage Method & No of weeks & Mean (unit) & Standard Deviation & Standard Error 0.0055 \\
\hline Designed Barn Storage & 14 & 1.7286 & .37092 & .09913 \\
\hline Pit Barn Storage & 14 & 3.2071 & .23027 & .06154 \\
\hline House Storage & 14 & 3.1071 & .48431 & .12944 \\
\hline Traditional Barn Storage & 14 & 3.3286 & .43928 & .11740 \\
\hline Total & 56 & 2.8429 & .75747 & .10122 \\
\hline
\end{tabular}

Table.7: Comparison of weight loss in big and small sized tuber yam under different storage methods

\begin{tabular}{|l|l|l|l|l|}
\hline Tuber Sized & Designed Storage & Pit Storage & House Storage & Traditional Barn \\
\hline Big size & $2.12 \pm 0.41$ & $4.16 \pm 0.40^{\mathrm{abc}}$ & $3.34 \pm 0.35^{\mathrm{a}}$ & $3.41 \pm 0.26^{\mathrm{a}}$ \\
\hline Small size & $1.734 \pm 0.31$ & $3.21 . \pm 0.35^{\mathrm{a}}$ & $3.11 \pm 0.48^{\mathrm{a}}$ & $3.33 \pm 0.44^{\mathrm{a}}$ \\
\hline
\end{tabular}

(a) $\mathrm{P}<0.05$, significantly different from designed storage

(b) $\quad \mathrm{P}<0.05$, significantly different from house storage (c) $\quad \mathrm{P}<0.05$, significantly different from traditional barn, values reported as means -+ standard deviation.

\section{BIG SIZED YAM TUBER}


Weight loss from designed storage was significantly difference from the one obtained from other storage methods (table 7). That of Pit Storage was significantly different from House Storage method $(\mathrm{P}=0.000, \mathrm{P}<0.5)$ and Traditional Barn $(\mathrm{P}=0.00, \mathrm{p}<0.05)$. Pit Storage produced the highest weight loss (table 9).

\section{SMALL SIZED YAM TUBER}

Table.8: LSD for big sized yam tuber weight loss under different storage methods at 0.05 level.

\begin{tabular}{|l|l|l|l|l|}
\hline (I) Storage Method & $(\mathbf{J})$ Storage Method & $\begin{array}{l}\text { Mean difference } \\
(\mathbf{I}-\mathbf{J})\end{array}$ & $\begin{array}{l}\text { Standard } \\
\text { Error }\end{array}$ & Significance \\
\hline Designed Storage & Pit Storage & $-2.03571^{*}$ & .13697 & .000 \\
& House Storage & $-1.22143^{*}$ & .13697 & .000 \\
& Traditional Barn & $-1.29286^{*}$ & .13697 & .000 \\
\hline Pit Storage & Designed Storage & $2.03571^{*}$ & .13697 & .000 \\
& House Storage & $.81442^{*}$ & .13697 & .000 \\
& Traditional Barn & $.74286^{*}$ & .13697 & .000 \\
\hline House Storage & Designed Storage & $1.22143^{*}$ & .13697 & .000 \\
& Pit Storage & $-.81429^{*}$ & .13697 & .000 \\
& Traditional Barn & $-07143 \mathrm{~ns}$ & .13697 & .000 \\
\hline Traditional Barn & Designed Storage & $1.29286^{*}$ & .13697 & .000 \\
& Pit Storage & $-.74286^{*}$ & .13697 & .000 \\
& House Storage & $-07143 \mathrm{~ns}$ & .13697 & .000 \\
\hline
\end{tabular}

Using the LSD to evaluate the big sized yam tuber weight loss from the different storage methods at 0.05 levels indicated that designed storage is significantly difference from Pit, House and Traditional Barn (table 8). Also Pit Storage showed significant difference from Designed, House and Traditional Barn (table 8). House Storage had no
Weight loss due to Pit Storage, House Storage and Traditional Storage were all significantly higher than that of Designed Storage (table 7). No significance difference in weight loss was observed between House Storage and Traditional Storage $(\mathrm{P}=0.142, \mathrm{P}>0.05)$, House Storage and Pit Storage $(\mathrm{P}=0.148, \mathrm{P}>0.05)$ although, Traditional Barn recorded the highest weight loss (table 7).

Table.9: LSD for small sized yam tuber weight loss under different storage methods at 0.05 level.

\begin{tabular}{|l|l|l|l|l|}
\hline Storage Method(I) & Storage method(J) & $\begin{array}{l}\text { Mean } \\
\text { Difference (I-J) }\end{array}$ & $\begin{array}{l}\text { Standard } \\
\text { Error }\end{array}$ & Significance \\
\hline Designed Storage & Pit Storage & $-1.47857^{*}$ & .14858 & .000 \\
& House Storage & $-1.37857^{*}$ & .14858 & .000 \\
& Traditional Barn & $-1.60000^{*}$ & .14858 & .000 \\
\hline Pit Storage & Designed Storage & $1.47857^{*}$ & .14858 & .000 \\
& House Storage & $.10000 \mathrm{Ns}$ & .14858 & .504 \\
& Traditional Barn & $.12143 \mathrm{Ns}$ & .14858 & .418 \\
\hline House Storage & Designed Storage & $1.37857^{*}$ & .14858 & .000 \\
& Pit Storage & $-.10000 \mathrm{Ns}$ & .14858 & .504 \\
& Traditional Storage & $-.22143 \mathrm{Ns}$ & .14858 & .412 \\
\hline Traditional Barn & Designed storage & $1.60000^{*}$ & .14858 & .000 \\
& Pit Storage & $.12143 \mathrm{Ns}$ & .14858 & .418 \\
& House Storage & $.22143 \mathrm{Ns}$ & .14858 & .412 \\
\hline
\end{tabular}

*: $\quad$ The mean difference is significant at the 0.05 level, Ns:

Not significant difference. 
From table 9, using the LSD to evaluate the small sized yam tuber at 0.05 , significant difference recorded that Designed Storage was significant different from Pit, House and Traditional Barn. While Pit Storage indicated significant difference from the Designed Storage but indicated no significant difference from House and Traditional Barn (table 9). Also Traditional Barn recorded significant difference from the Designed Storage but no significant difference from Pit and House Storage (table 9).To further compare and evaluate the effectiveness of each structure on the big sized yam, a graph of weigh loss versus number of weeks of storage from the four storing structure namely: Designed Barn, Pit Storage, House Storage and Traditional Barn was plotted. From the graph it is recorded that the Designed Barn had the least weight loss (fig 1). This further confirms the effectiveness of the Designed Barn in storing yam tubers. Another graph, fig. 2 also showed weight loss versus number of weeks for small size tuber yam which indicated the values of weight loss from a Designed Barn as the least compared to other storing structures.

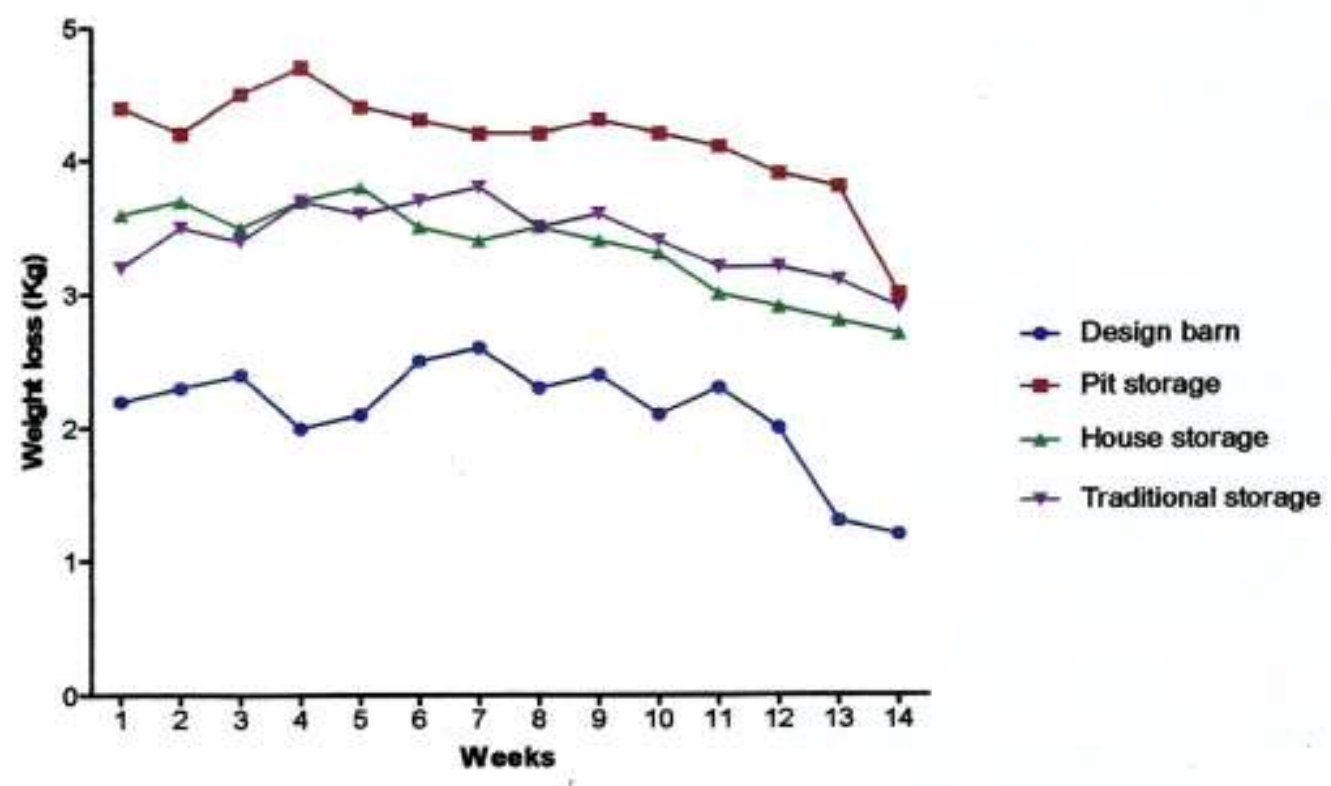

Fig.1: Weight loss versus number of weeks for big sized tuber yam under four storing methods.

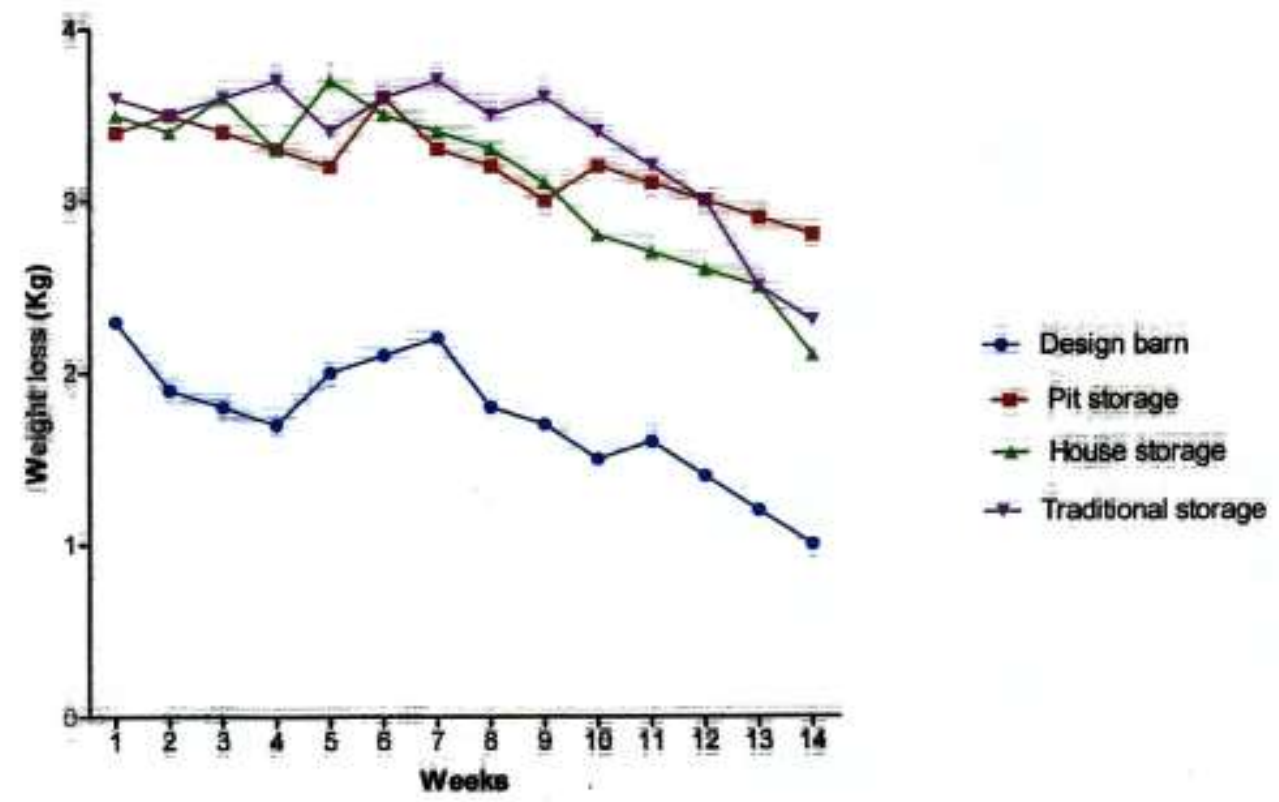

Fig.2: Weight loss versus number of weeks for small sized tuber yams under four storing methods. 


\section{ROTTING AND SPROUTING}

Record on rotting from the four storing structures namely Designed Barn, Pit Storage, House and Traditional Barn indicated the following numbers of tubers that rotted from the big sized yam tuber; Nil tubers from Designed Barn, 10 tubers from Pit, House and Traditional Barn respectively (table 10). While sprouting was recorded on 20 tubers from the Designed Barn, 30 tubers from Pit Storage, 20 tubers from House Storage and 30 tubers from Traditional Barn (table 10).From the records on small sized yam tuber quality, the following records on rotting were observed; Nil from the Designed Barn, 20 tubers from the Pit Storage, Nil from the House Storage and also Nil from the Traditional Storage (table 11). Still on the small sized yam table observation on sprouting indicated thus; Nil for Designed Barn, 80 tubers from Pit Storage, House Storage had 40 tubers and Traditional Barn had 60 tubers (table 11).
Evaluating on rotting on both big and small sized yam tubers, it is on record that no tuber got rotten from the Designed Barn (table 10 and table 11). This was attributed to sufficient spacing and shading within the structure and between the yam tubers which were placed individually on the shelves of the structure (fig. 3). While it was recorded in other storage structure on big sized tuber (table 10) with Pit Storage recording 20 tubers but none was recorded from other storage structures on small sized yam tuber quality (table 11). Sprouting was occurred in all the storage facilities on big sized yam tuber but less in the Designed and House Storage Barn (table 10), while Pit and Traditional Barns, recorded the same with highest number of sprouting tubers (table 10). Observation on small sized yam tuber on sprouting indicated the highest number from Pit Storage, followed by Traditional Barn (table 11).

Table.10: Effect of storage on big sized yam tubers quality under different storage structures.

\begin{tabular}{|l|l|c|c|c|}
\hline S/N & Storage Structure & No. of Tubers Stored & No. of Tubers Rotting & No. of Tubers Sprouting \\
\hline 1 & Designed Barn & 100 & Nil & 20 \\
\hline 2 & Pit Storage & 100 & 10 & 30 \\
\hline 3 & House Storage & 100 & 10 & 20 \\
\hline 4 & Traditional Barn & 100 & 10 & 30 \\
\hline
\end{tabular}

Table.11:Effect of storage on small sized yam tuber quality under different storage structures

\begin{tabular}{|l|l|c|c|c|}
\hline S/N & Storage Structure & No. of Tubers Stored & $\begin{array}{l}\text { No. of Tubers } \\
\text { Rotting }\end{array}$ & No. of Tubers Sprouting \\
\hline 1 & Designed Barn & 200 & 0 & 0 \\
\hline 2 & Pit Storage & 200 & 20 & 80 \\
\hline 3 & House Storage & 200 & 0 & 40 \\
\hline 4 & Traditional Barn & 200 & 0 & 60 \\
\hline
\end{tabular}

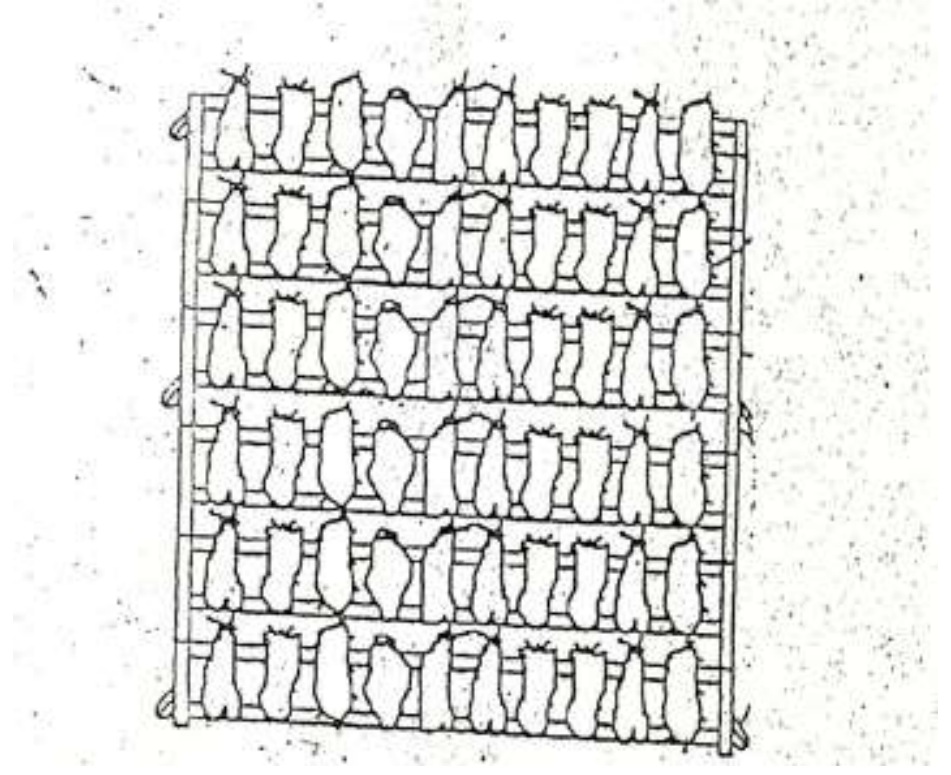

Fig. 3: Arrangement of tubers in designed barn. 


\section{CONCLUSION}

Based on the results of the study, the designed barn structure is very economical since it requires local materials for construction. The storage structure is also suitable for both small and large scale farmers in rural areas. It also alleviates the problems of deterioration of yam tubers and increases the financial benefits of yam farmers as well as provides good quality planting materials for farmers in Nigeria.

\section{REFERENCES}

[1] Adesuji S. A. (1982). Application of high technology to improvement of yam storage in Miege $\mathrm{J}$ and Lyonga S. N (ed) Yams Ignames Oxford, England et Clarendon press 312-319.

[2] Booth, R. H. (1974). Post harvest deterioration of topical root crops; losses and their control. Tropical science 16, pp49-63.

[3] Coursey D. G (1983). Post harvest losses in perishable foods in the developing world in Liebermann, M, ed. Post harvest physiology and crop protection. New York, U. S. A. plenum publishing.

[4] E. R. Terry, E.V. Doku, O. B. Arene N. M. Mahunga (1983). Tropical Root Crops. Production and Uses in Africa pp32.

[5] Matrin, W.J. (1955). Effect of Storage Temperature on Development of Internal Cork in Sweet Potato Roots Plant. Diseases Report 39, pp 620.

[6] Noon, R. A. (1978) Storage and market Diseases of Yams. Tropical Science 20 pp.1777 -188.

[7] Oji, M. A.(1999) Foods from Roots and other Crops with Recipes for variety of Dishes. New Africa Publishing Co Ltd Offong Close Akwakumo Orlu Road P. O. Box 1178, Owerri Imo State - Nigeria pp 16-22.

[8] Passam H. C. Wickham, L.D and Wilson L. A. (1982). Long Term Storage of Yam Tubers (DioscoreaAlata L) Tropical Science 24, 99-110.

[9] Tuber and Root Crops production manual series No. 9. (1982). pp 175-179. 